\title{
Faculty Status for Library Professionals: Its Effect on Job Turnover and Job Satisfaction among University Research Library Directors
}

\section{Michael Koenig, Ronald Morrison, and Linda Roberts}

\begin{abstract}
The authors investigated the relationship between the job turnover and job satisfaction of ARL university library directors relative to faculty status. The findings were that there did, in fact, seem to be a positive relationship between job satisfaction and faculty status. The provision of staff release time to pursue scholarly endeavors was correlated positively with the directors' reported job satisfaction, whereas "hollow faculty status," defined as nominal faculty status but without the provision of release time, was correlated negatively (both significant at the .05 level). Job turnover by itself was quite unrelated to the issue of faculty status.
\end{abstract}

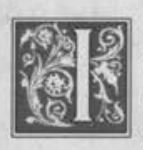

n 1973, Arthur McAnally and Robert Downs published a landmark article pointing out the recent dramatic increase in turnover rate among directors of university libraries. They traced this increase to numerous factors ranging from the growth in size and complexity of the institutions, the information explosion, and budget cuts, to increased stress and declining status for directors, all of which may have combined effectively to force them out of their jobs before they were ready to retire. ${ }^{1}$ To cope with these changes, the authors recommended better planning, creative budgeting, and improved services and organization.
However, as Dick Dougherty suggested in his 1989 introduction to a reprint of their article, things haven't changed much since then. ${ }^{2}$

Not only have pressures increased and status declined, but there is also frequently no pathway open to further advancement beyond the library directorship. Edward D. Garten observed that few chief library officers eventually move into senior academic positions such as vicepresident, provost, or president, perhaps because there is little opportunity in the course of their careers to build their resumés in relevant areas, such as curriculum design and development, faculty development, political coalition building, or external public relations. The director- 
ship of university libraries, he suggested, is marked by a lack of influence and power and essentially constitutes a marginal role within the larger university. ${ }^{3}$

Anne Woodsworth elaborated on this lack of career mobility, arguing that although library directors may appear to function at the pinnacle of their fields, within the college or university they are more accurately seen as middle managers. They are not only subject to all the stresses that middle managers experience, such as isolation and overwork, but they also lack any clear means for professional development. ${ }^{4}$

In a 1989 Library Journal article, Woodsworth pointed out another development since McAnally and Downs published their article. She suggested that library directors don't necessarily want to stay in their jobs indefinitely. Instead, "the best and the brightest" leave because of burnout after some years of coping with increasing pressures and demands. ${ }^{5}$ In addition, Michael Koenig and Herbert Stafford discussed a related issue, namely, the unusually extreme vertical stratification of the field; that is, the difficulty of moving horizontally in or out of academic research library directorships, particularly the difficulty of moving from corporate research library directorships to academic research library directorships, and the recruiting problem this poses for academic library directorships. ${ }^{6}$ Subsequently, Michael Buckland, Evelyn Daniel, and Richard Dougherty all have echoed the same concern about recruitment of "the best and the brightest."7-9

Recent literature focuses on the stress placed on library directors as a result of their middle-management status, but there is another factor that relates to stress: the presence or absence of faculty status for professional library staff members. ACRL's "Model Statement" recommending faculty status across the board has received a mixed reception, partly because faculty status typically brings with it expectations to carry out and publish research, even though the time and support necessary to do so may not be provided. ${ }^{10}$

Kee DeBoer and Wendy Culotta, for example, reviewed literature published in the 1980 s and found that academic librarians most often have some type of faculty or academic status, although perhaps not full faculty status. However, because librarians have little release time for research, DeBoer and Culotta harbor "doubts that faculty status is the best alternative for librarians." 11

Emily Werrell and Laura Sullivan, in a review of the literature from 1974 to 1985 , found that release time for research is severely lacking among those libraries that encourage or require it for promotion and tenure. Further, given a choice, librarians prefer to provide library service and leave publishing to the teaching faculty. ${ }^{12}$

In a review of thirty-six faculty status surveys from 1971 to 1984, Janet Krompart and Clara DiFelice found unclear requirements for tenure and promotion, and inconsistent provision of release time and funds for research and publication. ${ }^{13}$ Betsy Park and Robert Riggs surveyed 304 college and university libraries and discovered that 41 percent of the librarians had faculty rank and status, and that most of these institutions encouraged publication, but that anxiety over a "publish or perish" scenario seemed to be a major factor in the ambivalence expressed over faculty status. ${ }^{14}$

In contrast to the above studies, John Buschman, in a comparison with Krompart and DiFelice's data, found that nonfaculty status librarians were dissatisfied equally, citing isolation and lack of a peer group within the university, unclear systems for promotion, and lower salaries than faculty. In short, as one of Buschman's respondents reported, "The faculty rank/status issue is an ambiguous one and seems to make little actual difference in how librarians are treated."15

In fact, Judith Hegg found that librarians with faculty status had lower levels 
of job satisfaction than those without faculty status. ${ }^{16}$ Furthermore, in concluding a major literature survey, Rachel Applegate reiterated how past research has failed to support the idea that faculty status benefits either academic librarians or their institutions and called for abandoning the faculty status ideal in favor of other models. ${ }^{17}$ Most recently, Elizabeth Henry, Dana Caudle, and Paula Sullenger investigated the relationship between the existence of tenure and tenure requirements in academic libraries and the turnover of professional staff, and found that no significant relationship exists. ${ }^{18}$

Because the directors of academic libraries are also academic librarians, it is reasonable to suppose that the issues surrounding faculty status might have an effect on their positions, in addition to the stress already incumbent on it. In addition, a director's position as manager of other professionals who have faculty status may be different from a position in which they do not. A director may have less leverage over librarians with faculty status who may be tenured and therefore not vulnerable to termination and only marginally vulnerable to other sanctions. Therefore, it is possible that the presence or absence of faculty status at a given university might have an effect on the library director's perceived stress level and overall job satisfaction.

\section{The Hypothesis}

Librarians all know the reputation and the stereotype-the university library that is known or at least reputed to have a high director turnover rate because of its fractious and ungovernable cadre of professional library staff made and supported, if not confirmed in that fractiousness and ungovernability, by tenure. Is there some substance to that stereotype? The authors conceived this study with the hypothesis that there was likely to be some fire behind the smoke, that an academic research library director's tenure and satisfaction with the job would be adversely affected by having to manage a professional library staff with faculty status.

The thesis might be stated more formally as: Having to manage a library in which the library professional staff have tenure and faculty status increases the stress level of the director's position. More specifically, the thesis would be that the library director's position is functionally that of a classic line manager managing a service function in a complex, multifaceted environment, and, generally, is seen as such by his or her management. By contrast, the notion of tenure and faculty status inevitably carries with it the overtones of academic governance and collegiality in which the department head or

Having to manage a library in which the library professional staff have tenure and faculty status increases the stress level of the director's position.

dean manages - or better, leads - as first among equals. This dichotomy, it could be argued, creates a tension for the manager between the role he or she is expected to play by the institutional administration and the role he or she is expected to play by the library staff. The authors did not expect there to be a strong relationship, but they did anticipate a negative relationship between professional staff faculty status and the director's tenure and job satisfaction. Interestingly enough, the results of their study contradicted this thesis.

\section{Methodology}

The authors designed the following study, therefore, to evaluate the relationships between length of time on the job and job satisfaction among directors of academic and research libraries, and the presence or absence of faculty status for professional staff. In order to evaluate this issue, the authors mailed survey questionnaires to all academic ARL li- 
brary directors requesting the following information:

- Please give the number of years you have been director.

- What was the length of tenure of your two most recent predecessors?

- Please rank your overall satisfaction with your job. (Here appeared a seven-point rating scale ranging from "Terribly frustrating, not what I expected when I entered this field [1]" to "Great job. Love it!" [7].)

To obtain data on the policy of a given institution regarding faculty status and rank for professional library staff, the authors also mailed the following questions to the personnel officer at each ARL library surveyed:

- Do the professional librarians have faculty status? If so, roughly what percentage of them do?

- Is release time provided for research and publication? Is research and publication activity a significant component of tenure and promotion decisions?

- Is there any union or functional equivalent that represents professional staff (for example, a staff association that takes part in salary or contract negotiations)? If so, roughly what percentage of professional staff are included?

- Is there any other social or professional mechanism that serves some of the functions of faculty status, particularly professional recognition? (For example, at Yale University, a professional library staff member can be, and often is, elected a Fellow of one of the colleges.) If so, roughly what percentage of professional staff are included?

The library director and personnel officers at each library were surveyed separately to minimize the possibility of the directors' detecting the study's interest in the relationship between turnover/job satisfaction and tenure and faculty status. This correlation could have caused bias in their responses.

\section{Results}

The response rate to the questionnaires was gratifyingly high, particularly because usable results required that both the library director and the personnel director reply to separate questionnaires. There are 120 ARL libraries, of which twelve either are not academic libraries or are otherwise not relevant to a study of the effect of faculty status. Of the remaining sample of 108 libraries, the authors received complete data (both respondents) from seventy-eight libraries for a (joint) response rate of 72 percent. The authors believe that the comparative simplicity of the data-gathering instruments contributed greatly to the high response rate.

The two dependent variables were job satisfaction as reported by the current library directors and the average job tenure of the current directors and their two predecessors. Indeed, job satisfaction did relate to the issue of faculty status, and although the relationships were not particularly strong statistically, they were highly significant and rather stronger than would have been anticipated given the plethora of other potentially influential variables. The three most salient correlations were the correlations, or in one case the lack thereof, between the director's job satisfaction and (1) whether the professional staff enjoyed faculty status, (2) the provision of release time for professional staff to pursue scholarly activities, and ( 3 ) faculty status but without the provision of release time (see table 1 ).

The correlations among any of the independent variables above and the measures of job turnover (the incumbent's tenure on the job, that of the predecessor, the predecessor once removed, or the average of all three) were essentially insignificant (all were low, and none was statistically significant, even at the .1 level). This is entirely consistent with the findings of Henry, Caudle, and Sullenger, who examined the relationship between overall staff turnover and tenure in academic libraries..$^{18}$ 


\begin{tabular}{|llll|}
\hline \multicolumn{4}{c}{$\begin{array}{l}\text { TABLE 1 } \\
\text { Key Relationships with Director's Job Satisfaction }\end{array}$} \\
\hline \hline Variable & $\begin{array}{l}\text { Correlation } \\
\text { Coefficient }\end{array}$ & P. Value & Comments \\
\hline $\begin{array}{l}\text { Faculty Status (whether the } \\
\text { professional staff were described } \\
\text { as having faculty status) }\end{array}$ & -.0925 & .421 & $\begin{array}{l}\text { Essentially no } \\
\text { relationship }\end{array}$ \\
$\begin{array}{l}\text { Release Time (whether the } \\
\text { professional staff enjoyed release } \\
\text { time to pursue scholarly activities) }\end{array}$ & .4452 & .002 & $\begin{array}{l}\text { A nontrivial } \\
\text { relationship, highly } \\
\text { significant statistically }\end{array}$ \\
$\begin{array}{l}\text { "Hollow Faculty Status" (nominal } \\
\text { faculty status but without release time) }\end{array}$ & -.2441 & .031 & $\begin{array}{l}\text { A modest correlation, } \\
\text { but still statistically } \\
\text { significant }\end{array}$ \\
\hline
\end{tabular}

The data were also subjected to a factor analysis, and although two factors did emerge, they were not crisp and the authors were not successful in tagging them with meaningful conceptual labels.

\section{Conclusion}

It appears, with one caveat, that faculty status for library professionals, rather than adversely affecting the job satisfaction of academic library directors, is correlated positively with job satisfaction. That caveat is quite intriguing. It implies strongly that mere nominal faculty status-faculty status that does not include release time to pursue scholarly or research activities, that is, simply declaring that professional library staff have faculty status but not actually providing the time and wherewithal to pursue researchdoes not make a positive contribution. It further implies that what does correlate with the director's job satisfaction is an environment in which the library professional staff are treated as functional faculty equivalents and given release time to pursue scholarly activities. "Hollow faculty status," nominal faculty status but without release time, is negatively correlated with the directors' reported job satisfaction. Although these results are indeed interesting, it is important not to imply causality to correlation. Nevertheless, the results certainly hint at a more positive role for faculty status than generally is accorded in the current literature.

\section{Notes}

1. Arthur M. McAnally and Robert B. Downs, "The Changing Role of Directors of University Libraries", College \& Research Libraries 50 (May 1989): 307-27 (reprinted from 1973).

2. Richard M. Dougherty, "The Changing Role of Directors of University Libraries: Introduction to a Reprint of a CERL Classic," College \& Research Libraries 50 (May 1989): 305-06.

3. Edward D. Garten, "Observations on Why So Few Chief Library Officers Move into Senior Academic Administration," Library Administration and Management 2 (Mar. 1988): 95-98.

4. Anne Woodsworth, "Library Directors As Middle Managers: A Neglected Resource," Library Administration and Management 3 (winter 1989): 24-27.

5. - "Getting off the Library Merry-Go-Round: McAnally and Downs Revisited; the Best and the Brightest Directors Are Burned Out," Library Journal 114 (May 1989): 35-38.

6. Michael E. D. Koenig and Herbert Stafford, "Myths, Misconceptions \& Management," Library Journal 109 (Oct. 1984): 1897-1902.

7. Michael Buckland, "Theme V: The School, Its Faculty and Students," in Changing Technology and Education for Librarianship and Information Science (Greenwich, Conn.: JAI Pr., 1985), 127. 
8. Evelyn Daniel, "Commentary" on "Current Developments in Education for Librarianship and Information Science" by Edward G. Holley, in Changing Technology and Education for Librarianship and Information Science (Greenwich, Conn.: JAI Press, 1985), 78.

9. Richard M. Dougherty, "Commentary" on "Changing Technology and the Personnel Requirements of Research Libraries" by Carlton Rochell, in Changing Technology and Education for Librarianship and Information Science (Greenwich, Conn.: JAI Press, 1985), 45.

10. ACRL/Academic Status Committee, "Model Statement of Criteria and Procedures for Appointment, Promotion in Academic Rank, and Tenure for College and University Librarians (Revision of the 1973 Model Statement)," College \& Research Libraries News 48 (May 1987): 24754 .

11. Kee DeBoer and Wendy Culotta, "The Academic Librarian and Faculty Status in the 1980s: A Survey of the Literature," College \& Research Libraries 48 (May 1987): 215-23.

12. Emily Werrell and Laura Sullivan, "Faculty Status for Academic Librarians: A Review of the Literature," College \& Research Libraries 48 (Mar. 1987): 95-103.

13. Janet Krompart and Clara L. DiFelice, "A Review of Faculty Status Surveys, 1971-1984," Journal of Academic Librarianship 13 (Mar. 1987): 14-18.

14. Betsy Park and Robert Riggs, "Status of the Profession: A 1989 National Survey of Tenure and Promotion Policies for Academic Librarians," College \& Research Libraries 52 (May 1991): 275-89.

15. John Buschman, "The Flip Side of Faculty Status," College and Research Libraries News 50 (Dec. 1989): 972-76.

16. Judith L. Hegg, "Faculty Status: Some Expected and Some Not-So Expected Findings," Journal of Library Administration 6 (winter 1985/86): 67-79.

17. Rachel Applegate, "Deconstructing Faculty Status: Research and Assumptions," Journal of Academic Librarianship 19 (July 1993): 158-64.

18. Elizabeth C. Henry, Dana M. Caudle, and Paula Sullenger, "Tenure and Turnover in Academic Libraries," College \& Research Libraries 55 (Sept. 1994): 419-35.

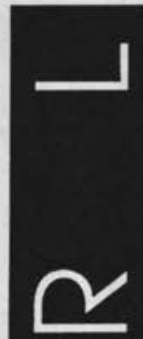

\section{ACRL University Librapy Statistics, 1994-95}

Library Research Center, Graduate School of Library \& Information Science, University of Illinois at UrbanaChampaign, comp.

Data from more than 100 participating libraries. Library categories include collections, personnel, expenditures, and interlibrary loan. Institutional categories include degrees offered, enrollment size, and faculty size.

Price to be announced

0-8389-7831-2, 1996

Order from ALA Order Fulfillment, $155 \mathrm{~N}$. Wacker Dr., Chicago, IL 60611; tel.: (800) 545-2433 (press 7); fax: (312) 836-9958 